\title{
Serum concentrations of activin and follistatin are elevated and run in parallel in patients with septicemia
}

\author{
Uwe Michel, Sandra Ebert, David Phillips ${ }^{1}$ and Roland $\mathrm{Nau}^{2}$ \\ Laboratory of Neurobiology, Department of Neurology and Psychiatry, von-Siebold-Straße 5, University of Göttingen, Göttingen, Germany, \\ ${ }^{1}$ Monash Institute of Reproduction and Development, Monash University, Clayton, Victoria 3168, Australia and ${ }^{2}$ Department of Neurology, \\ Robert-Koch-Str. 40, University of Göttingen, Göttingen, Germany \\ (Correspondence should be addressed to U Michel, Department of Neurology, Robert-Koch-Str. 40, 37075 Göttingen, Germany; \\ Email: umichel@gwdg.de)
}

\begin{abstract}
Objective: Activin is a growth and differentiation factor of many cell types, and has recently been implicated in inflammatory processes. Clinical data linking activin and its binding protein, follistatin (FS), are lacking. We measured serum levels of activin and FS in patients diagnosed with septicemia. Patients and measurements: Eight male and seven female patients of different ages, various forms of septicemia and different clinical outcome were investigated and compared with age- and sex-matched healthy controls. Serum concentrations of FS, activin, C-reactive protein (CRP) and blood leukocyte counts were determined during septicemia.

Results: The median of the maximum activin concentrations of septicemic patients was 3.9-fold higher than in age- and sex-matched healthy control subjects $(P<0.01)$; the median of the maximum FS concentrations was 2.6 -fold higher $(P<0.01)$. The highest increase of activin in septicemic patients was approximately 15.8-fold, whereas FS increased by up to 13.2-fold above normal. FS, activin and CRP serum levels generally paralleled each other, but were not correlated with leukocyte counts or clinical outcome.

Conclusions: Circulatory concentrations of activin and FS are elevated in patients diagnosed with septicemia, consistent with potential roles in the systemic inflammatory response.
\end{abstract}

European Journal of Endocrinology 148 559-564

\section{Introduction}

Activin affects the growth and differentiation of many cell types, stimulates the secretion of follicle-stimulating hormone from the pituitary gland and inhibits growth hormone, prolactin, and adrenocorticotropin release (1-3). Follistatin (FS) specifically binds to activin. As a result, circulating FS 315 neutralizes activin activity by preventing the interaction of the cytokine with its type II receptors (4) and, furthermore, cell surface-bound FS 288 facilitates the lysosomal degradation of activin (5). Both FS and activin mRNAs show a broad tissue distribution (6-8). FS and activin are detectable in serum (9-18), and their concentrations in serum increase with age $(18,19)$. At present, however, the sources of FS and activin in serum are unknown. Current data suggest that tissue-specific balances of FS and activin govern the growth and differentiation of responsive cell types in an autocrine/paracrine manner (for reviews see 20, 21).

We and others have documented an emerging role for activin and FS in the body's innate immune response. For instance, activin and FS are secreted by various cell types in response to inflammatory compounds in vitro $(22-30)$. Moreover, in some examples of inflammatory processes such as wound healing, inflammatory bowel disease and rheumatoid arthritis, increased activin and/or FS expression has been noted (31-33). While we have reported previously that serum FS concentrations were elevated in patients with septicemia (34), there are few if any data published on activin profiles in clinically important inflammatory syndromes. Therefore, in this study we examined both activin and FS serum responses in patients who were hospitalized and undergoing treatment for septicemia.

\section{Materials and methods}

As part of their routine clinical management, serial blood samples were collected from seven female and eight male patients of different ages who suffered from septic infections of different grades of severity. After completion of the clinical routine analyses, FS 
and activin were measured in the remnants of serum samples. Since the patients were critically ill, no extra blood samples were drawn for the purposes of this study. The samples were stored frozen at $-20^{\circ} \mathrm{C}$ until assayed. Since FS and activin serum levels increase with age $(18,19)$, serum samples from age- and sexmatched healthy volunteers served as controls. All samples from diseased and healthy persons were treated in the same way.

Patients were categorized for septicemia according to the American College of Chest Physicians/Society of Critical Care Medicine (ACCP/SCCM) Consensus criteria (manifestation of two or more of the following clinical conditions: body temperature $>38^{\circ} \mathrm{C}$ or $<36{ }^{\circ} \mathrm{C}$; heart rate $>90$ beats $/ \mathrm{min}$; respiratory rate $>20$ breaths/min or $\mathrm{PaCO}_{2}<32 \mathrm{mmHg}$; white blood cell count $>12000$ cells $/ \mathrm{mm}^{3},<4000$ cells $/ \mathrm{mm}^{3}$, or $>10 \%$ immature forms) (35). For 12 of 15 patients the diagnosis of septicemia was proven by culture of the infectious organism from blood. In three cases the culture of the infectious organism failed due to rapid implementation of antibiotic treatment.

Activin A concentrations in serum were measured using a specific ELISA which detects both FS-bound and free activin (13), with the following modifications. The standard used was human recombinant (hr) activin A as described previously (14). The assay sensitivity was $0.1 \mathrm{ng} / \mathrm{ml}$ and the intra- and interassay coefficients of variation were $4.7 \%$ and $7.8 \%$ respectively. Serum samples were assayed against the standard diluted in $5 \%$ bovine serum albumin in phosphatebuffered saline $(0.01 \mathrm{~mol} / \mathrm{l})$. FS concentrations in serum were measured with a radioimmunoassay validated for human FS as previously described (36).
The standard employed was hrFS 288, but the assay cross-reacts with hrFS 315 (35.9\%). The assay sensitivity was $2.0 \mathrm{ng} / \mathrm{ml}$ and the intra- and interassay coefficients of variation were both $<4.9 \%$. The assay measures total FS (free and bound). Numbers of leukocytes, serum creatinine levels, and serum C-reactive protein (CRP) levels were determined by clinical routine methods in the Department of Clinical Chemistry of the University of Göttingen.

Differences in the serum concentrations of FS and activin between septic patients and matched healthy volunteers were analyzed by paired $t$-test. Correlations between measured parameters were calculated with Pearson correlation. The software was Graph Pad Prism 3.0 (Graph Pad, San Diego, CA, USA).

\section{Results and discussion}

Peak activin and FS serum concentrations of patients with septicemia were elevated compared with concentrations in age- and sex-matched controls (Table 1). The median of the maximum activin concentration of septicemic patients was 3.9-fold higher than the median in healthy controls $(P<0.01)$; the median of the maximum FS concentrations of septicemic patients was 2.6-fold higher than the median of the FS concentrations in healthy controls $(P<0.01)$. The magnitude of the activin and FS increase during septicemia varied among individuals and there was no close association between FS/activin serum concentrations and clinical outcome.

Figure 1 depicts the individual profiles of serum activin and $\mathrm{FS}$ in the seven female $(\mathrm{A})$ and eight male

Table 1 Comparison of activin and FS serum concentrations from patients with septicemia and sex- and age-matched healthy controls.

\begin{tabular}{|c|c|c|c|c|c|c|c|c|}
\hline \multirow[b]{2}{*}{ Number } & \multirow[b]{2}{*}{ Diagnosis } & \multirow[b]{2}{*}{ Age } & \multirow[b]{2}{*}{ Sex } & \multicolumn{2}{|c|}{$\begin{array}{l}\text { Septicemia } \\
(\mathrm{ng} / \mathrm{ml})\end{array}$} & \multicolumn{2}{|c|}{$\begin{array}{l}\text { Control } \\
\text { (ng/ml) }\end{array}$} & \multirow[b]{2}{*}{ Outcome } \\
\hline & & & & Activin & FS & Activin & FS & \\
\hline 1 & Sepsis (Staph. aureus) & 64 & f & 0.42 & 25.77 & 0.15 & 4.84 & Deceased \\
\hline 2 & Sepsis \& meningitis (Strep. pneu.) & 72 & $f$ & 0.65 & 14.48 & 0.18 & 10.4 & Cured \\
\hline 3 & Sepsis \& meningitis (Neisseria meningitidis) & 42 & $f$ & 0.15 & 5.27 & 0.07 & 5.7 & Cured \\
\hline 4 & Sepsis \& meningitis (Strep. pneu.) & 56 & f & 0.59 & 15.00 & 0.1 & 5.6 & Deceased \\
\hline 5 & Sepsis \& encephalitis \& endocarditis (coagulase-negative Staph.) & 84 & f & 1.97 & 39.64 & 0.18 & 10.4 & Deceased* \\
\hline 6 & Sepsis (E. coli) & 67 & f & 0.61 & 42.28 & 0.16 & 5.7 & Deceased \\
\hline 7 & Sepsis (Neisseria meningitidis) & 33 & $f$ & 2.31 & 76.14 & 0.08 & 5.1 & Deceased \\
\hline 8 & Sepsis & 66 & $\mathrm{~m}$ & 0.62 & 16.82 & 0.13 & 3.88 & Deceased \\
\hline 9 & Sepsis \& meningitis (Strep. pneu.) & 37 & $\mathrm{~m}$ & 0.19 & 16.39 & 0.11 & 5.75 & Cured \\
\hline 10 & Sepsis (Staph. aureus) & 70 & $\mathrm{~m}$ & 0.81 & 21.9 & 0.15 & 6.48 & Deceased \\
\hline 11 & Sepsis \& meningitis (Neisseria meningitidis) & 46 & $\mathrm{~m}$ & 0.18 & 5.26 & 0.13 & 5.34 & Cured \\
\hline 12 & Sepsis (coagulase-negative Staph.) & 75 & $\mathrm{~m}$ & 0.19 & 15.01 & 0.18 & 11.3 & Cured \\
\hline 13 & Sepsis & 62 & $\mathrm{~m}$ & 0.43 & 9.97 & 0.17 & 10.84 & Deceased \\
\hline 14 & Sepsis \& pneumonia & 76 & $\mathrm{~m}$ & 0.28 & 12.47 & 0.18 & 9.36 & Cured \\
\hline \multirow[t]{2}{*}{15} & Sepsis (Staph. epidermidis) & 71 & $\mathrm{~m}$ & 0.28 & 14.88 & 0.17 & 7.71 & Cured \\
\hline & Median & & & 0.59 & 15 & 0.15 & 5.75 & \\
\hline
\end{tabular}

Staph., Staphylococcus; Strep., Streptococcus; pneu., pneumoniae; E. coli, Escerichia coli; m, male; f, female.

Control vs septicemia: $P=0.004$ for activin concentrations and $P=0.009$ for FS concentrations (paired Wilcoxon rank test).

*Patient died soon after discharge from clinic. 
A

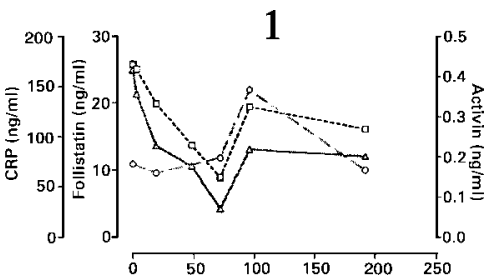

4
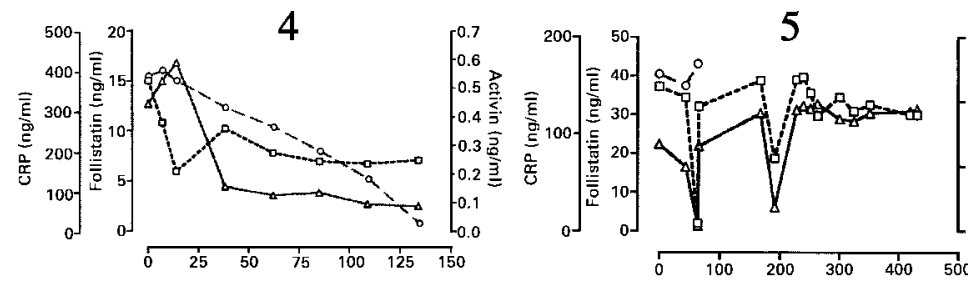

2
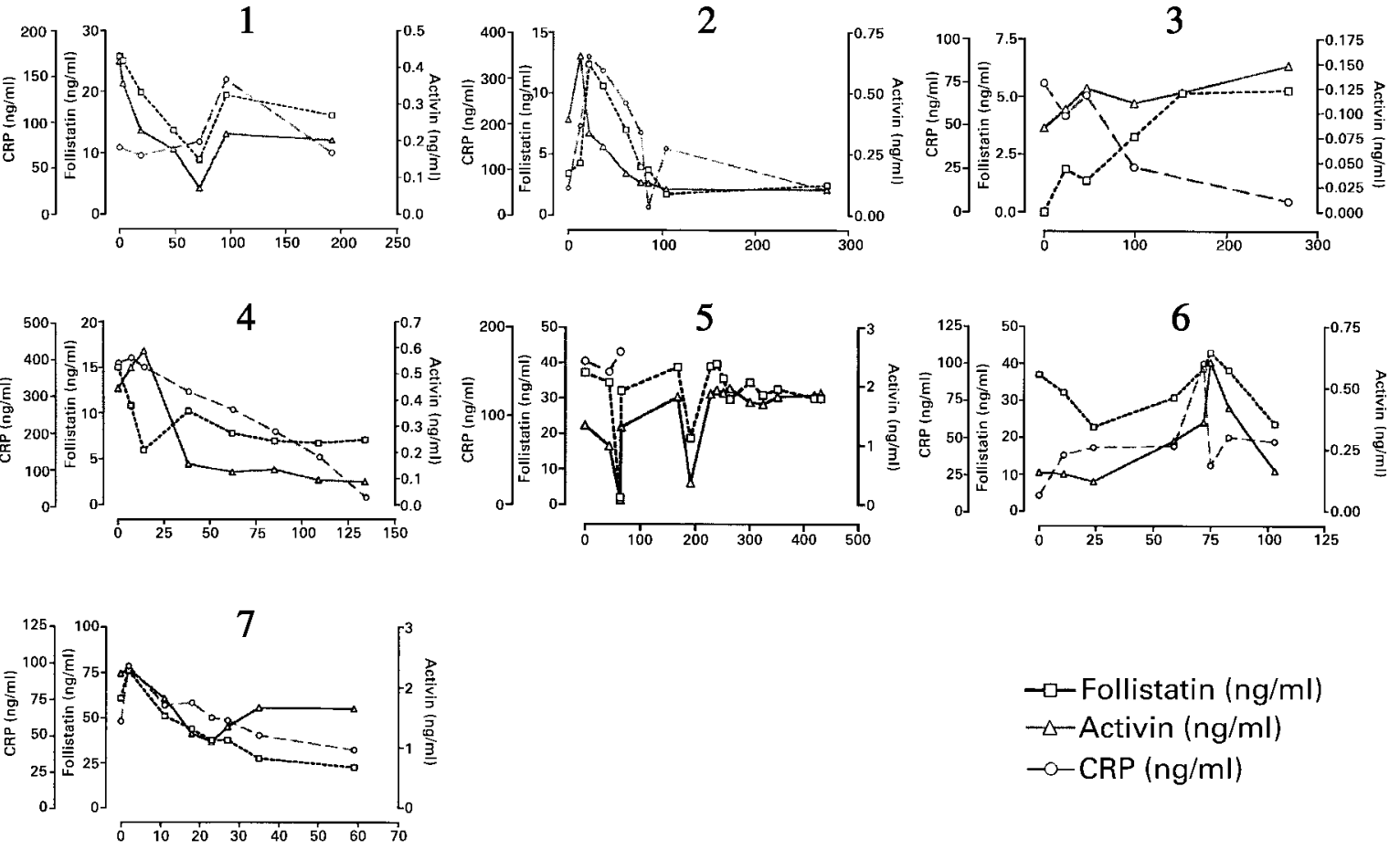

$\rightarrow-$ Follistatin ( $\mathrm{ng} / \mathrm{ml})$

$\triangle$ Activin $(\mathrm{ng} / \mathrm{ml})$

$\rightarrow$ CRP (ng/ml)

\section{hours}

\section{B}

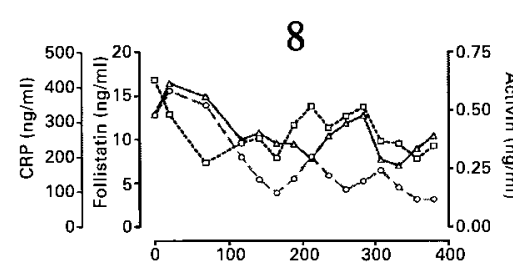

11
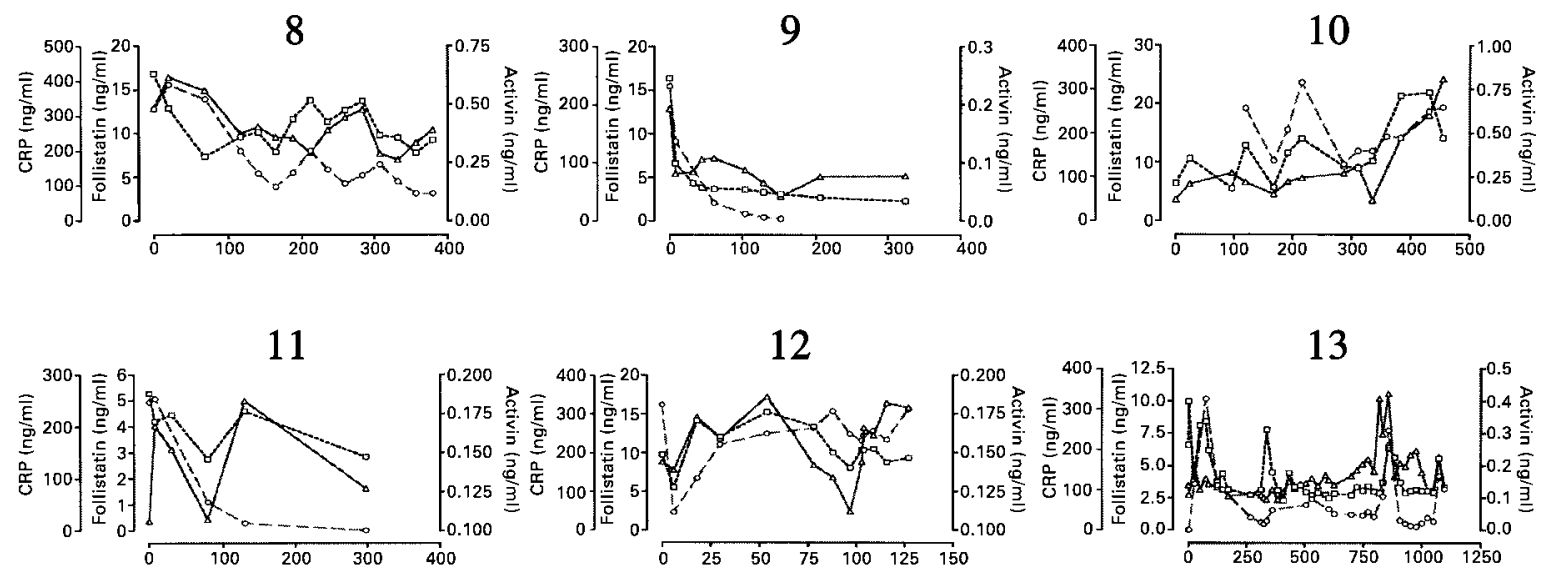

12
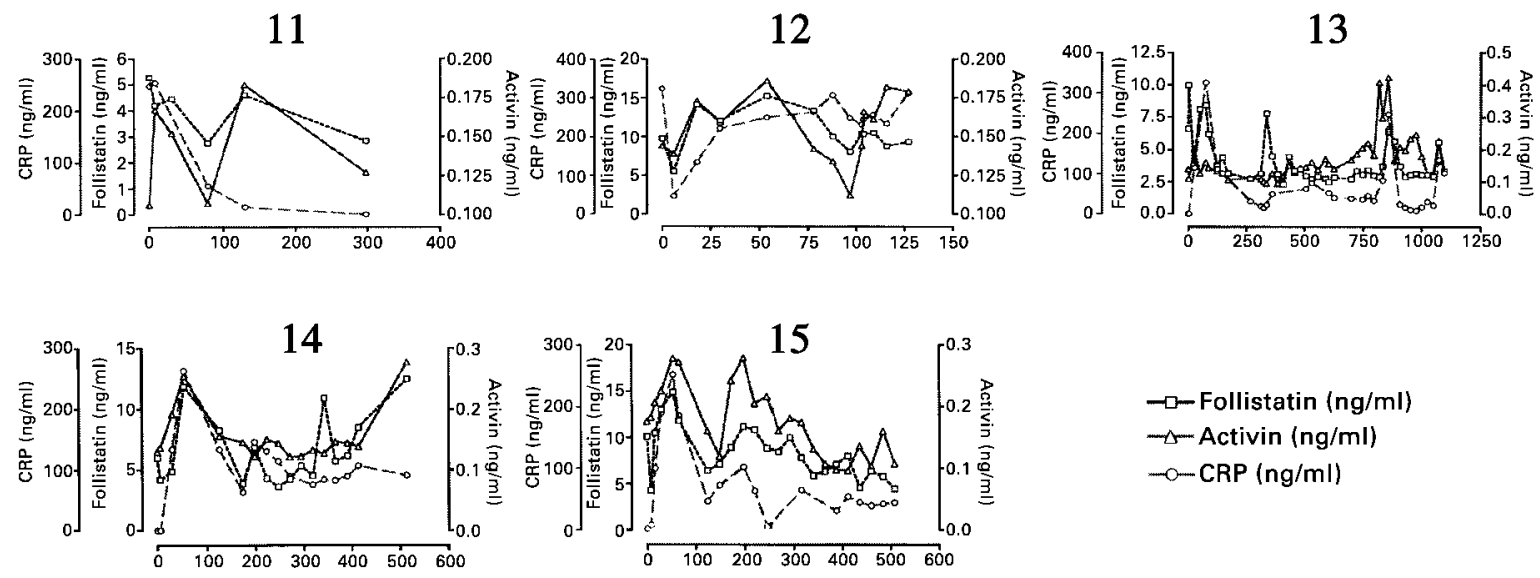

\section{hours}

Figure 1 Time course of activin, FS and CRP concentrations in serum of female (A) and male (B) patients with septicemia. Patient numbers correspond to the numbers in Table 1. In each diagram on the X-axis, the time points of blood sampling are shown (first sample taken at $\mathrm{Oh}$ ). On the left $\mathrm{Y}$-axis, $\mathrm{FS}$ serum concentrations in $\mathrm{ng} / \mathrm{ml}$ and on the right $\mathrm{Y}$-axis activin serum concentrations in $\mathrm{ng} / \mathrm{ml}$ are shown. The second $\mathrm{Y}$-axis on the left is the scale for the CRP serum concentrations in $\mathrm{ng} / \mathrm{ml}$. 
(B) patients and the corresponding serum levels of CRP, an indicator of inflammation. Most of the diagrams in Fig. 1 show that activin and FS serum levels track each other and follow changes in CRP levels. Overall, activin and FS concentrations were correlated with each other $\left(r^{2}=0.64\right)$. There was no apparent relationship between activin and FS serum concentrations and the number of leukocytes $\left(r^{2}=0.09\right)$. The parallel profiles of FS, activin, and CRP suggest a causal relationship between bacterial infection and elevated activin and FS serum levels. The observed increases in FS and activin serum concentrations during the inflammatory response are in accordance with observations in animal experiments, where interleukin-1 $\beta$ or lipopolysaccharide (LPS) injections caused significantly elevated FS and activin serum levels $(23,37,38)$. The onset of septicemia is often unnoticed, whereas in most cases blood sampling commenced with obvious signs of the disease; this made it impossible to determine whether the serum concentration of activin, FS or CRP was the first to rise at the beginning of the infection.

The normal creatinine serum concentrations in most patients and the molecular size of the glycosylated FS $(39-45 \mathrm{kDa})$ and activin $(25 \mathrm{kDa})$ molecules make an altered renal function as the sole cause of increased serum concentrations in sepsis unlikely. The tissues or cell types which contribute to the activin and FS serum levels in normal and infected animals or humans are currently unknown. Leukocyte counts did not show a strong correlation with FS and activin levels in septicemic patients $\left(r^{2}=0.09\right)$ and therefore leukocytes may not be the primary source of increased FS and activin levels during septicemia. Nevertheless, the lack of correlation with total leukocyte counts does not rule out the possibility that specific populations of cells preferentially release activin and/or FS, as has been documented for human monocytes in response to LPS $(28,39)$.

Well-balanced steady-state levels of FS and activin govern the growth, differentiation and behavior of many cell types (see Introduction), and pharmacological doses of FS and activin affect pituitary hormone secretion in animals $(17,40-48)$. Therefore, it is conceivable that elevated FS and activin serum levels can also influence endocrine hormone patterns or paracrine interactions in tissues. Elevated serum concentrations of activin and/or FS have been reported in a number of pathological states, including hypertension during pregnancy, renal failure, liver dysfunction and various carcinomas $(16,49-54)$. Nevertheless, the role of these proteins in the disease process is poorly defined. The need for a well-balanced equilibrium of FS and activin could be one explanation for the tight correlation of both factors in serum during sepsis $\left(\mathrm{r}^{2}=\right.$ 0.64). In terms of inflammatory processes, emerging data suggest activin can have both pro- and antiinflammatory effects on cell responses and cytokine production, which may account for its elevated levels in patients with septicemia. Nevertheless, these studies have focused largely on cell cultures of primary immune cells or cell lines. Therefore, the pathophysiological relevance of release of activin and FS to septicemia remains to be elucidated.

In conclusion, activin and FS serum concentrations are elevated in patients with septicemia. The rises are accompanied by increased serum CRP levels. Detailed studies are necessary to determine the cell type(s) responsible for the $\mathrm{FS}$ and activin increases in the serum of septicemic individuals and to elucidate the pathophysiological relevance of this phenomenon.

\section{Acknowledgements}

The authors would like to acknowledge the technical assistance of Anne O'Connor and Sue Hayward. This work was supported by grants from the DFG $\mathrm{Na}$ 165/4-2 (to R N), a Program Grant from the National Health and Medical Research Council of Australia 143786 (to D P), and the Verein zur Förderung von Forschung, Wissenschaft und Lehre an der Neurologischen Klinik der Universität Göttingen (to $U$ M and S E).

\section{References}

1 Billestrup N, Gonzalez-Manchon C, Potter E \& Vale W. Inhibition of somatotroph growth and growth hormone biosynthesis by activin in vitro. Molecular Endocrinology 19904 356-362.

2 Kitaoka M, Kojima I \& Ogata E. Activin-A: a modulator of multiple types of anterior pituitary cells. Biochemical and Biophysical Research Communications 1988157 48-54.

3 Vale W, Rivier J, Vaughan J, McClintock R, Corrigan A, Woo W et al. Purification and characterization of an FSH releasing protein from porcine ovarian follicular fluid. Nature 1986321 776-779.

4 de Winter JP, ten Dijke P, de Vries CJ, van Achterberg TA, Sugino $\mathrm{H}$, de Waele $\mathrm{P}$ et al. Follistatins neutralize activin bioactivity by inhibition of activin binding to its type II receptors. Molecular and Cellular Endocrinology 1996116 105-114.

5 Hashimoto O, Nakamura T, Shoji H, Shimasaki S, Hayashi Y \& Sugino H. A novel role of follistatin, an activin-binding protein, in the inhibition of activin action in rat pituitary cells. Endocytotic degradation of activin and its acceleration by follistatin associated with cell-surface heparan sulfate. Journal of Biological Chemistry 1997272 13835-13842.

6 Meunier H, Rivier C, Evans RM \& Vale W. Gonadal and extragonadal expression of inhibin $\alpha, \beta \mathrm{A}$, and $\beta \mathrm{B}$ subunits in various tissues predicts diverse functions. PNAS $1988 \mathbf{8 5} 247-251$.

7 Michel U, Albiston A \& Findlay JK. Rat follistatin: gonadal and extragonadal expression and evidence for alternative splicing. Biochemical and Biophysical Research Communications 1990173 401-407.

8 Schneider O, Nau R \& Michel U. Comparative analysis of follistatin-, activin beta A- and activin beta B-mRNA steady-state levels in diverse porcine tissues by multiplex $S 1$ nuclease analysis. European Journal of Endocrinology 2000142 537-544.

9 Demura R, Suzuki T, Tajima S, Mitsuhashi S, Odagiri E, Demura H et al. Human plasma free activin and inhibin levels during the menstrual cycle. Journal of Clinical Endocrinology and Metabolism 199376 1080-1082. 
10 Demura R, Suzuki T, Tajima S, Mitsuhashi S, Odagiri E, Eto Y et al. Competitive protein binding assay for activin A/EDF using follistatin determination of activin levels in human plasma. Biochemical and Biophysical Research Communications 1992185 1148-1154.

11 Gilfillan CP \& Robertson DM. Development and validation of a radioimmunoassay for follistatin in human serum. Clinical Endocrinology 199441 453-461.

12 Khoury RH, Wang QF, Crowley WF Jr, Hall JE, Schneyer AL, Toth $\mathrm{T}$ et al. Serum follistatin levels in women: evidence against an endocrine function of ovarian follistatin. Journal of Clinical Endocrinology and Metabolism $1995 \mathbf{8 0} 1361-1368$.

13 Knight PG, Muttukrishna S \& Groome NP. Development and application of a two-site enzyme immunoassay for the determination of 'total' activin-A concentrations in serum and follicular fluid. Journal of Endocrinology 1996148 267-279.

14 McFarlane JR, Foulds LM, Pisciotta A, Robertson DM \& de Kretser DM. Measurement of activin in biological fluids by radioimmunoassay, utilizing dissociating agents to remove the interference of follistatin. European Journal of Endocrinology 1996134 481-489.

15 Sakai R, Shiozaki M, Tabuchi M \& Eto Y. The measurement of activin/EDF in mouse serum: evidence for extragonadal production. Biochemical and Biophysical Research Communications 1992188 921-926.

16 Sakamoto Y, Shintani Y, Harada K, Abe M, Shitsukawa K \& Saito S. Determination of free follistatin levels in sera of normal subjects and patients with various diseases. European Journal of Endocrinology $1996135345-351$.

17 Tilbrook AJ, de Kretser DM, Dunshea FR, Klein R, Robertson DM, Clarke IJ et al. The testis is not the major source of circulating follistatin in the ram. Journal of Endocrinology 1996149 55-63.

18 Wakatsuki M, Shintani Y, Abe M, Liu ZH, Shitsukawa K \& Saito S. Immunoradiometric assay for follistatin: serum immunoreactive follistatin levels in normal adults and pregnant women. Journal of Clinical Endocrinology and Metabolism 199681 630-634.

19 Loria P, Petraglia F, Concari M, Bertolotti M, Martella P, Luisi S et al. Influence of age and sex on serum concentrations of total dimeric activin A. European Journal of Endocrinology 1998139 487-492.

20 Michel U, Esselmann J \& Nieschlag E. Expression of follistatin messenger ribonucleic acid in Sertoli cell-enriched cultures: regulation by epidermal growth factor and protein kinase C-dependent pathway but not by follicle-stimulating hormone and protein kinase A-dependent pathway. Acta Endocrinologica $1993 \quad 129$ 525-531.

21 Phillips DJ. New developments in the biology of inhibins, activins and follistatins. Trends in Endocrinology and Metabolism 200112 94-96.

22 Hübner G \& Werner S. Serum growth factors and proinflammatory cytokines are potent inducers of activin expression in cultured fibroblasts and keratinocytes. Experimental Cell Research 1996228 106-113.

23 Jones KL, Brauman JN, Groome NP, de Kretser DM \& Phillips DJ. Activin A release into the circulation is an early event in systemic inflammation and precedes the release of follistatin. Endocrinology 2000141 1905-1908.

24 Keelan JA, Zhou RL \& Mitchell MD. Activin A exerts both pro- and anti-inflammatory effects on human term gestational tissues. Placenta $20002138-43$.

25 Michel U, Schneider O, Kirchhof C, Meisel S, Smirnov A, Wiltfang J et al. Production of follistatin in porcine endothelial cells: differential regulation by bacterial compounds and the synthetic glucocorticoid RU 28362. Endocrinology 1996137 4925-4934.

26 Phillips DJ, de Kretser DM, Pfeffer A, Chie WN \& Moore LG. Follistatin has a biphasic response but follicle-stimulating hormone is unchanged during an inflammatory episode in growing lambs. Journal of Endocrinology $1998 \mathbf{1 5 6}$ 77-82.

$27 \mathrm{Yu}$ J, Shao LE, Frigon NL Jr, Lofgren J \& Schwall R. Induced expression of the new cytokine, activin A, in human monocytes: inhibition by glucocorticoids and retinoic acid. Immunology 1996 $88368-374$.
28 Erämaa M, Hurme M, Stenman UH \& Ritvos O. Activin A/erythroid differentiation factor is induced during human monocyte activation. Journal of Experimental Medicine $1992 \mathbf{1 7 6}$ 1449-1452.

29 Shao LE, Frigon NL Jr, Yu A, Palyash J \& Yu J. Contrasting effects of inflammatory cytokines and glucocorticoids on the production of activin A in human marrow stromal cells and their implications. Cytokine 199810 227-235.

30 Mohan A, Asselin J, Sargent IL, Groome NP \& Muttukrishna S. Effect of cytokines and growth factors on the secretion of inhibin A, activin A and follistatin by term placental villous trophoblasts in culture. European Journal of Endocrinology 2001145 505-511.

31 Hübner G, Brauchle M, Gregor M \& Werner S. Activin A: a novel player and inflammatory marker in inflammatory bowel disease? Laboratory Investigation 199777 311-318.

32 Hübner G, Hu Q, Smola H \& Werner S. Strong induction of activin expression after injury suggests an important role of activin in wound repair. Developmental Biology 1996173 490-498.

33 Yu EW, Dolter KE, Shao LE \& Yu J. Suppression of IL-6 biological activities by activin A and implications for inflammatory arthropathies. Clinical and Experimental Immunology $1998 \mathbf{1 1 2}$ 126-132.

34 Michel U, Shintani Y \& Nau R. Serum follistatin concentrations are increased in patients with septicaemia. Clinical Endocrinology 199848 413-417.

35 American College of Chest Physicians/Society of Critical Care Medicine Consensus Conference. Definitions for sepsis and organ failure and guidelines for the use of innovative therapies in sepsis. Critical Care Medicine 199220 864-874.

36 O'Connor AE, McFarlane JR, Hayward S, Yohkaichiya T, Groome NP \& de Kretser DM. Serum activin A and follistatin concentrations during human pregnancy: a cross-sectional and longitudinal study. Human Reproduction 199914 827-832.

37 Klein R, Clarke IJ, Hedger MP \& Robertson DM. Plasma follistatin concentrations increase following lipopolysaccharide administration in sheep. Clinical and Experimental Pharmacology and Physiology 199623 754-755.

38 Phillips DJ, Hedger MP, McFarlane JR, Klein R, Clarke IJ, Tilbrook AJ et al. Follistatin concentrations in male sheep increase following sham castration/castration or injection of interleukin-1 beta. Journal of Endocrinology $1996 \mathbf{1 5 1} 119-124$.

39 Shao L, Frigon NL Jr, Sehy DW, Yu AL, Lofgren J, Schwall R et al. Regulation of production of activin A in human marrow stromal cells and monocytes. Experimental Hematology 199220 1235-1242.

40 DePaolo LV, Shimonaka M \& Ling N. Regulation of pulsatile gonadotropin secretion by estrogen, inhibin, and follistatin (activin-binding protein) in ovariectomized rats. Biology of Reproduction 199246 898-904.

41 DePaolo LV, Shimonaka M, Schwall RH \& Ling N. In vivo comparison of the follicle-stimulating hormone-suppressing activity of follistatin and inhibin in ovariectomized rats. Endocrinology $1991128668-674$.

42 Inouye S, Guo Y, DePaolo L, Shimonaka M, Ling N \& Shimasaki S. Recombinant expression of human follistatin with 315 and 288 amino acids: chemical and biological comparison with native porcine follistatin. Endocrinology 1991129 815-822.

43 Lee S \& Rivier C. Effect of repeated activin-A treatment on the activity of the hypothalamic-pituitary-gonadal axis of the adult male rat. Biology of Reproduction $1997 \mathbf{5 6} 969-975$.

44 Ling N, Ying SY, Ueno N, Shimasaki S, Esch F, Hotta M et al. Pituitary FSH is released by a heterodimer of the beta-subunits from the two forms of inhibin. Nature $1986321779-782$.

45 Meriggiola MC, Dahl KD, Mather JP \& Bremner WJ. Follistatin decreases activin-stimulated FSH secretion with no effect on GnRH-stimulated FSH secretion in prepubertal male monkeys. Endocrinology 1994134 1967-1970.

46 Carroll RS, Kowash PM, Lofgren JA, Schwall RH \& Chin WW. In vivo regulation of FSH synthesis by inhibin and activin. Endocrinology $19911293299-3304$. 
47 Stouffer RL, Woodruff TK, Dahl KD, Hess DL, Mather JP \& Molskness TA. Human recombinant activin-A alters pituitary luteinizing hormone and follicle-stimulating hormone secretion, follicular development, and steroidogenesis, during the menstrual cycle in rhesus monkeys. Journal of Clinical Endocrinology and Metabolism 199377 241-248.

48 Woodruff TK, Krummen LA, Lyon RJ, Stocks DL \& Mather JP. Recombinant human inhibin A and recombinant human activin A regulate pituitary and ovarian function in the adult female rat. Endocrinology $19931322332-2341$.

49 Harada K, Shintani Y, Sakamoto Y, Wakatsuki M, Shitsukawa K \& Saito S. Serum immunoreactive activin A levels in normal subjects and patients with various diseases. Journal of Clinical Endocrinology and Metabolism 199681 2125-2130.

50 Lambert-Messerlian GM, DePasquale SE, Maybruck WM, Steinhoff MM \& Gajewski WH. Secretion of activin A in recurrent epithelial ovarian carcinoma. Gynecologic Oncology $1999 \mathbf{7 4}$ 93-97.

51 Patella S, Phillips DJ, de Kretser DM, Evans LW, Groome NP \& Sievert W. Characterization of serum activin-A and follistatin and their relation to virological and histological determinants in chronic viral hepatitis. Journal of Hepatology 200134 576-583.

52 Pirisi M, Fabris C, Luisi S, Santuz M, Toniutto P, Vitulli D et al. Evaluation of circulating activin-A as a serum marker of hepatocellular carcinoma. Cancer Detection and Prevention 200024 $150-155$.

53 Reis FM, Cobellis L, Tameirao LC, Anania G, Luisi S, Silva IS et al. Serum and tissue expression of activin A in postmenopausal women with breast cancer. Journal of Clinical Endocrinology and Metabolism $2002872277-2282$.

54 Yuen MF, Norris S, Evans LW, Langley PG \& Hughes RD. Transforming growth factor-beta 1 , activin and follistatin in patients with hepatocellular carcinoma and patients with alcoholic cirrhosis. Scandinavian Journal of Gastroenterology 200237 233-238.

Received 15 November 2002

Accepted 4 February 2003 